\title{
Prevalence and correlates of hazardous, harmful or dependent alcohol use and drug use amongst persons 15 years and older in South Africa: Results of a national survey in 2017
}

\begin{tabular}{|c|c|}
\hline \multicolumn{2}{|c|}{$\begin{array}{l}\text { Authors: } \\
\text { Supa Pengpid } \\
\text { Karl Peltzer } \\
\text { Shandir Ramlagan }\end{array}$} \\
\hline \multicolumn{2}{|c|}{$\begin{array}{l}\text { Affiliations: } \\
{ }^{1} \text { ASEAN Institute for Health } \\
\text { Development, Mahidol } \\
\text { University, Salaya, } \\
\text { Phutthamonthon, Nakhon } \\
\text { Pathom, Thailand }\end{array}$} \\
\hline \multicolumn{2}{|c|}{$\begin{array}{l}{ }^{2} \text { Department of Research } \\
\text { Administration and } \\
\text { Development, University } \\
\text { of Limpopo, Polokwane, } \\
\text { South Africa }\end{array}$} \\
\hline \multicolumn{2}{|c|}{$\begin{array}{l}{ }^{3} \text { Department of Human and } \\
\text { Social Capabilities, Human } \\
\text { Sciences Research Council, } \\
\text { Pretoria, South Africa }\end{array}$} \\
\hline \multicolumn{2}{|c|}{$\begin{array}{l}\text { Corresponding author: } \\
\text { Karl Peltzer, } \\
\text { kfpeltzer@gmail.com }\end{array}$} \\
\hline \multicolumn{2}{|c|}{$\begin{array}{l}\text { Dates: } \\
\text { Received: } 19 \text { Nov. } 2020 \\
\text { Accepted: } 15 \text { Feb. } 2021 \\
\text { Published: } 23 \text { Mar. } 2021\end{array}$} \\
\hline \multicolumn{2}{|c|}{$\begin{array}{l}\text { How to cite this article: } \\
\text { Pengpid S, Peltzer K, } \\
\text { Ramlagan S. Prevalence and } \\
\text { correlates of hazardous, } \\
\text { harmful or dependent } \\
\text { alcohol use and drug use } \\
\text { amongst persons } 15 \text { years } \\
\text { and older in South Africa: } \\
\text { Results of a national survey in } \\
\text { 2017. Afr J Prm Health Care } \\
\text { Fam Med. 2021;13(1), a2847. } \\
\text { https://doi.org/10.4102/ } \\
\text { phcfm.v13i1.2847 }\end{array}$} \\
\hline \multicolumn{2}{|l|}{ Read online: } \\
\hline 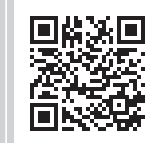 & $\begin{array}{l}\text { Scan this QR } \\
\text { code with your } \\
\text { smart phone or } \\
\text { mobile device } \\
\text { to read online. }\end{array}$ \\
\hline
\end{tabular}

Background: Harmful alcohol and illicit drug use significantly contribute the burden of disease.

Aim: This study aimed to assess the prevalence and correlates of hazardous, harmful or dependent alcohol (HHDA) use and drug use amongst persons 15 years and older in South Africa.

Setting: Population-based survey.

Method: In a national cross-sectional 2017 survey, 39210 persons 15 years and older (Median $=34$ years) responded to a questionnaire on substance and health variables. The prevalence of HHDA use was $10.3 \%$ and past 3-month drug use $8.6 \%$.

Results: In adjusted logistic regression analysis, men of middle age (25-34 year olds) with higher education, urban residence, drug use and psychological distress were positively associated and Indian or Asian and white population groups were negatively associated with HHDA. Women of middle age (25-34 year old) and mixed race, residing on rural farms and urban areas, with drug use and psychological distress were positively associated and older age (55 years and older) and Indians or Asians were negatively associated with HHDA. In adjusted logistic regression analysis, men, having Grade 8-11 education, mixed race, being unemployed, and the HHDA used were positively associated and middle and older age ( 25 years and older) and being a student or learner were negatively associated with past 3-month any drug use. Women, who were mixed race, Indians or Asians, with the HHDA use were positively associated and older age ( 45 years and older) were negatively associated with the past 3-month drug use.

Conclusion: About one in 10 participants with several sociodemographic and health indicators was identified to be associated with HHDA and any drug use.

Keywords: alcohol use; drug use; adolescents; adults; health variables; South Africa.

\section{Introduction}

Harmful alcohol and illicit drug use is a significant contributor to the global burden of disease. . $^{1,2}$ Globally, alcohol use contributed to $5.3 \%$ of all deaths and $5.0 \%$ of all disability-adjusted life years (DALYs) in 2016. ${ }^{1}$ The corresponding figures for South Africa in 2000 were $7.1 \%$ and 7.0\%, respectively. ${ }^{4}$ Diverse alcohol use patterns have been observed in African countries. ${ }^{5,6,7,8}$ In a 2015 national survey in Kenya, $6.7 \%$ of the adult population engaged in hazardous or harmful alcohol use. ${ }^{9}$ In a 2008 national population-based survey of persons 15 years and older in South Africa, the prevalence of hazardous, harmful or dependent alcohol (HHDA) use was 9.0\%, 17.0\% amongst men and $2.9 \%$ amongst women. ${ }^{10}$

The estimated global past-year prevalence of illicit drug use was $5.3 \%$ in $2014^{2}$ and $3.8 \%$ for cannabis, $0.77 \%$ for amphetamines, $0.37 \%$ for opioid and $0.35 \%$ for cocaine use in $2015 .{ }^{11}$ In the 25 country World Mental Health Survey, 'lifetime drug use disorders prevalence increased with country income: $0.9 \%$ in low-/lower-middle income countries, $2.5 \%$ in upper-middle income countries and $4.8 \%$ in highincome countries'.$^{12}$ In Nigeria, the past-year prevalence of illicit drug use amongst adults was $14.4 \% .{ }^{13}$ In a 2012 national population-based survey in persons 15 years and older in South Africa, the prevalence of past 3-month drug use was $4.4 \%$ (4.0\% for cannabis use, $0.4 \%$ sedatives, $0.3 \%$ opiates, $0.3 \%$ amphetamines, $0.2 \%$ inhalants and $0.1 \%$ hallucinogens use in the past 3 months). ${ }^{14}$ There is a lack

Copyright: @ 2021. The Authors. Licensee: AOSIS. This work is licensed under the Creative Commons Attribution License. 
of more recent national population-based data on the prevalence and correlates of HHDA and drug use in South Africa.

As previously reviewed, ${ }^{14,15}$ factors associated with HHDA and/or drug use may include male sex, middle adulthood, specific ethnic groups, lower socioeconomic status, unemployed, urban residence and other substance use. In addition, several studies have shown the comorbidity of HHDA with drug use and psychological distress, ${ }^{16,17}$ as well as the comorbidity of drug use with HHDA and psychological distress. ${ }^{6}$ Epidemiological population-based surveys are needed to target interventions to prevent HHDA and drug use. The study aimed to assess the prevalence and correlates of HHDA and drug use amongst persons 15 years and older in South Africa.
Methods

\section{Study design and participants}

The data utilised in this study were obtained from a cross-sectional, nationally representative household-based survey conducted in 2017 in South Africa. The multistage stratified random cluster sampling approach of the survey is described elsewhere. ${ }^{18}$ In summary, the mid-year population estimates ${ }^{19}$ were utilised to select 1000 small area layers (SALs) that were stratified by province, locality type and race groups. A maximum of 15 households were randomly selected from each of the 1000 SALs. In each household, all household members, who resided in that household the previous night, were eligible to participate. ${ }^{18}$

TABLE 1: Sample characteristics and distribution of substance use.

\begin{tabular}{|c|c|c|c|c|c|c|c|c|}
\hline \multirow[t]{3}{*}{ Variable } & \multicolumn{2}{|c|}{ Sample } & \multicolumn{3}{|c|}{ Hazardous, harmful or dependent alcohol use } & \multicolumn{3}{|c|}{ Any drug use } \\
\hline & & & Total & Male & Female & Total & Male & Female \\
\hline & $N$ & $\%$ & $\%$ & $\%$ & $\%$ & $\%$ & $\%$ & $\%$ \\
\hline All & 39210 & - & 10.3 & 16.5 & 4.6 & 8.6 & 13.3 & 4.1 \\
\hline \multicolumn{9}{|l|}{ Sex } \\
\hline Female & 23112 & 51.7 & - & - & - & - & - & - \\
\hline Male & 16098 & 48.3 & - & - & - & - & - & - \\
\hline \multicolumn{9}{|l|}{ Age in years } \\
\hline $15-17$ & 3852 & 7.1 & 4.4 & 6.1 & 2.7 & 6.3 & 8.4 & 4.0 \\
\hline $15-24$ & 10863 & 24.1 & 9.5 & 13.5 & 5.5 & 10.2 & 15.4 & 5.1 \\
\hline $25-34$ & 8749 & 27.2 & 14.9 & 23.0 & 6.8 & 11.1 & 17.9 & 4.5 \\
\hline $35-44$ & 6523 & 19.2 & 10.4 & 16.6 & 4.1 & 7.9 & 12.0 & 3.7 \\
\hline $45-54$ & 5315 & 13.1 & 9.0 & 14.7 & 3.8 & 6.4 & 9.6 & 3.5 \\
\hline 55 or more & 7760 & 16.5 & 5.1 & 10.2 & 1.6 & 4.4 & 6.2 & 3.1 \\
\hline \multicolumn{9}{|l|}{ Education } \\
\hline Grade 0-7 & 18901 & 37.3 & 7.8 & 11.8 & 4.2 & 7.0 & 10.5 & 4.0 \\
\hline Grade 8-11 & 9871 & 26.5 & 13.2 & 20.8 & 5.6 & 11.3 & 19.1 & 3.7 \\
\hline Grade 12 or more & 12362 & 36.1 & 11.0 & 17.9 & 4.3 & 8.1 & 12.0 & 4.4 \\
\hline \multicolumn{9}{|l|}{ Population group } \\
\hline African black people & 30675 & 79.3 & 10.4 & 17.2 & 4.2 & 8.4 & 13.7 & 3.6 \\
\hline mixed race & 4303 & 8.8 & 13.5 & 19.4 & 10.9 & 10.8 & 17.2 & 6.4 \\
\hline Indian or Asian people & 2310 & 2.9 & 5.5 & 5.7 & 1.1 & 8.9 & 8.9 & 4.5 \\
\hline White people & 1922 & 8.9 & 7.4 & 11.2 & 3.3 & 7.4 & 8.6 & 5.9 \\
\hline \multicolumn{9}{|l|}{ Employment status } \\
\hline Employed/self-employed & 11931 & 36.0 & 12.2 & 17.4 & 4.8 & 8.9 & 12.3 & 4.1 \\
\hline Unemployed & 20649 & 50.2 & 9.7 & 17.5 & 4.5 & 8.8 & 15.9 & 4.0 \\
\hline Student/pupil/learner & 5400 & 12.4 & 8.0 & 10.9 & 5.1 & 6.7 & 8.9 & 4.6 \\
\hline Sick/disabled/unable/others & 748 & 1.4 & 8.7 & 14.6 & 2.6 & 6.7 & 9.7 & 3.7 \\
\hline \multicolumn{9}{|l|}{ Residence } \\
\hline Rural informal & 13675 & 26.0 & 6.2 & 11.6 & 1.9 & 7.1 & 11.7 & 3.6 \\
\hline Rural farms & 4263 & 5.0 & 9.6 & 12.3 & 5.8 & 8.8 & 12.2 & 4.2 \\
\hline Urban & 21372 & 69.0 & 12.0 & 18.5 & 5.7 & 9.1 & 14.0 & 4.3 \\
\hline \multicolumn{9}{|l|}{ Province } \\
\hline Western Cape & 2860 & 12.2 & 14.4 & 19.7 & 9.2 & 9.9 & 14.9 & 5.1 \\
\hline Eastern Cape & 2970 & 10.7 & 8.0 & 12.6 & 4.0 & 4.8 & 8.3 & 1.7 \\
\hline Northern Cape & 2030 & 2.0 & 15.3 & 22.7 & 7.9 & 11.3 & 16.5 & 6.0 \\
\hline Free State & 1753 & 5.1 & 15.2 & 23.6 & 7.2 & 10.3 & 17.0 & 4.1 \\
\hline KwaZulu-Natal & 13512 & 18.6 & 4.5 & 7.8 & 1.9 & 8.9 & 14.9 & 4.0 \\
\hline North-West & 2498 & 6.8 & 13.0 & 22.3 & 4.5 & 8.3 & 11.3 & 5.6 \\
\hline Gauteng & 6183 & 27.2 & 13.0 & 20.3 & 5.3 & 9.3 & 14.4 & 4.0 \\
\hline Mpumalanga & 5054 & 7.9 & 7.8 & 11.7 & 3.7 & 7.0 & 8.7 & 5.4 \\
\hline Limpopo & 2350 & 9.5 & 8.3 & 15.3 & 2.3 & 8.3 & 13.9 & 3.5 \\
\hline \multicolumn{9}{|l|}{ Psychological distress } \\
\hline No & 31307 & 79.6 & 9.8 & 15.6 & 4.1 & 8.3 & 12.8 & 3.8 \\
\hline Yes & 7750 & 20.4 & 12.2 & 20.6 & 6.3 & 9.5 & 16.0 & 5.0 \\
\hline
\end{tabular}




\section{Study procedure}

All eligible household members had to individually complete an informed consent form in private with the study fieldworker prior to being enrolled into the study. All questions that the respondent had during consent or interview were answered by the fieldworker or team supervisor. The respondent had the option to end the interview at any time without consequence. The household head or delegated household authority completed a household questionnaire, which captured demographic and household situation information and each individual in the household completed an individual questionnaire. ${ }^{18}$ The survey questionnaire was captured electronically by the fieldworker on a Mercer A105 tablet utilising Census and Survey Processing System (CSPro) software. Data were collected from December 2016 to February 2018. For this paper, data from the household and individual questionnaires were used. We restricted the sample to those who were 15 years and older and who completed the alcohol use measurement.

\section{Measures}

\section{Substance use variables}

Hazardous, harmful or dependent alcohol was assessed using the Alcohol Use Disorders Identification Test (AUDIT) $)^{20}$ and was scored as in a previous survey in South Africa. ${ }^{10}$ Amongst adults (20 years and above), the cut-off score is 8 or more ${ }^{20}$ and amongst adolescents (15-19 years) 5 or more ${ }^{21}$ for classifying HHDA use. Cronbach's alpha for the AUDIT was 0.87 in this sample.

Drug use in the past 3 months was assessed with seven items of the 'Alcohol, Smoking and Substance Involvement Screening Test (ASSIST)', for example, 'In the past 3 months, how often have you used cannabis (dagga, marijuana, pot, grass, hash, etc.?'. ${ }^{22}$ One item was added 'Whoonga (mixture of heroin, dagga = cannabis and antiretrovirals)' and classified under opiates. ${ }^{14}$ 'Response options ranged from $1=$ never to $5=$ almost daily. Any drug used in the past 3 months was coded as 1 and never as 0 '. ${ }^{14}$ 'All items were added together to indicate the prevalence of any drug use in the past 3 months ${ }^{\prime} .^{14}$ Cronbach alpha for the ASSIST in this sample was 0.91.

Sociodemographic factors included age, sex, highest educational level, population group (African black, Coloured, Indian or Asian, white and others), employment status, province and residence status. ${ }^{18}$ Statistics South Africa asks people to describe themselves in the census in terms of five racial population groups, which is useful because of relevant differences between these population groups in terms of various health and other indicators. ${ }^{10}$

Psychological distress was assessed with the Kessler Psychological Distress Scale (K10), with scores 20 or more, indicating psychological distress. ${ }^{23}$ Cronbach's alpha for the K10 was 0.92 in this sample.

TABLE 2: Demographic distribution of the prevalence of past 3 month drug use.

\begin{tabular}{|c|c|c|c|c|c|c|c|}
\hline \multirow[t]{2}{*}{ Variable } & Cannabis & Cocaine & Amphetamine & Inhalants & Sedatives & Hallucinogens & Opiates \\
\hline & $\%$ & $\%$ & $\%$ & $\%$ & $\%$ & $\%$ & $\%$ \\
\hline All & 7.8 & 1.8 & 1.5 & 1.3 & 1.7 & 1.2 & 1.2 \\
\hline \multicolumn{8}{|l|}{ Sex } \\
\hline Female & 3.5 & 1.5 & 1.4 & 1.4 & 1.7 & 1.3 & 1.5 \\
\hline Male & 12.4 & 2.1 & 1.5 & 1.2 & 1.7 & 1.2 & 2.0 \\
\hline \multicolumn{8}{|l|}{ Age in years } \\
\hline $15-17$ & 6.0 & 1.4 & 1.2 & 1.2 & 1.4 & 1.2 & 1.8 \\
\hline $15-24$ & 9.5 & 2.1 & 1.8 & 1.6 & 1.7 & 1.6 & 2.2 \\
\hline $25-34$ & 10.0 & 1.9 & 1.6 & 1.3 & 2.0 & 1.2 & 1.7 \\
\hline $35-44$ & 7.0 & 1.6 & 1.2 & 1.1 & 1.5 & 1.0 & 1.6 \\
\hline $45-54$ & 5.8 & 1.5 & 1.3 & 1.4 & 1.8 & 1.3 & 1.6 \\
\hline 55 or more & 4.1 & 1.3 & 1.1 & 1.1 & 1.5 & 1.0 & 1.2 \\
\hline \multicolumn{8}{|l|}{ Population group } \\
\hline African black people & 7.8 & 1.8 & 1.5 & 1.4 & 1.7 & 1.3 & 1.9 \\
\hline mixed race & 10.3 & 1.1 & 1.6 & 0.7 & 1.9 & 0.4 & 0.7 \\
\hline Indian or Asian people & 6.1 & 2.5 & 1.5 & 1.4 & 2.1 & 1.6 & 1.7 \\
\hline White people & 6.3 & 1.5 & 1.2 & 1.1 & 1.8 & 1.2 & 1.0 \\
\hline \multicolumn{8}{|l|}{ Residence } \\
\hline Rural informal & 6.6 & 2.2 & 1.7 & 1.6 & 1.6 & 1.5 & 1.9 \\
\hline Rural farms & 7.7 & 1.4 & 1.2 & 1.4 & 1.6 & 1.2 & 1.6 \\
\hline Urban & 8.3 & 1.6 & 1.4 & 1.2 & 1.8 & 1.2 & 1.6 \\
\hline \multicolumn{8}{|l|}{ Province } \\
\hline Western Cape & 8.9 & 1.5 & 1.4 & 0.6 & 1.6 & 0.7 & 1.1 \\
\hline Eastern Cape & 4.4 & 0.6 & 0.7 & 0.4 & 0.6 & 0.4 & 0.9 \\
\hline Northern Cape & 10.8 & 2.4 & 1.9 & 1.6 & 2.3 & 1.6 & 2.4 \\
\hline Free State & 9.6 & 1.1 & 0.9 & 1.0 & 1.9 & 1.0 & 1.2 \\
\hline KwaZulu-Natal & 8.2 & 2.4 & 2.1 & 2.0 & 2.2 & 1.9 & 2.2 \\
\hline North-West & 7.3 & 2.6 & 2.7 & 2.8 & 3.1 & 2.5 & 3.4 \\
\hline Gauteng & 8.5 & 0.9 & 0.6 & 0.6 & 1.1 & 0.5 & 1.0 \\
\hline Mpumalanga & 6.4 & 3.3 & 3.0 & 3.2 & 2.9 & 2.9 & 3.3 \\
\hline Limpopo & 7.4 & 3.0 & 1.6 & 1.6 & 1.7 & 1.4 & 2.1 \\
\hline
\end{tabular}




\section{Ethical considerations}

Approval for the survey was granted by the 'Human Sciences Research Council (HSRC) Research Ethics Committee (REC: 4/18/11/15)'. Approval was also granted by the Centers for Disease Control and Prevention (CDC's) Center for Global Health (CGH). Written informed consent was obtained from all participants.

\section{Data analysis}

All statistical analyses were conducted using Statistics and data (STATA) software version 14.0 (Stata Corporation, College Station, TX, United States). The data were weighted to make the sample representative of the target population in South Africa. Descriptive statistics were used to summarise the sample and substance use prevalence characteristics. Unadjusted and adjusted (including variables significant at $p<$ 0.05 in univariate analysis) logistic regression stratified by sex was used to predict HHDA and past 3-month drug use prevalence. Taylor linearisation methods were applied to account for the complex study design and the sampling weight. Results from logistic regression analyses are reported as odds ratios (ORs) and 95\% confidence intervals (CIs). Missing values were excluded and $p<0.05$ was considered significant.

\section{Results}

\section{Characteristics of the sample and substance use}

The sample comprised 39210 persons 15 years and older (Median $=34$ years, interquartile range $=25-48): 48.3 \%$ were men and $51.7 \%$ were women, $36.1 \%$ had Grade 12 or more education education and $79.3 \%$ were African black by population group or ethnicity. More than one in three participants $(36.0 \%)$ were employed or self-employed, $69.0 \%$ lived in urban areas and $20.4 \%$ reported psychological distress. More than one in 10 respondents (10.3\%) engaged in HHDA, $16.5 \%$ amongst males and $4.6 \%$ amongst females, and past 3-month drug use was $8.6 \%$, $13.3 \%$ amongst males and $4.1 \%$ amongst females (see Table 1).

\section{Distribution of past 3-month drug use pattern}

The most common drug used was cannabis (7.8\%), $12.4 \%$ amongst males and $3.5 \%$ amongst females. The prevalence of cocaine use was $1.8 \%$, followed by sedeatives $1.7 \%$, amphetamine $1.5 \%$, inhalents $1.3 \%$, hallucinogens $1.2 \%$ and opiates $1.2 \%$ (see Table 2 ).

TABLE 3: Associations with hazardous, harmful or dependent alcohol consumption amongst men

\begin{tabular}{|c|c|c|c|c|c|c|}
\hline \multirow[t]{2}{*}{ Variable } & \multicolumn{3}{|c|}{ Simple logistic regression } & \multicolumn{3}{|c|}{ Multiple logistic regression } \\
\hline & Crude OR & $95 \% \mathrm{Cl}$ & $p$ & Adjusted OR & $95 \% \mathrm{Cl}$ & $p$ \\
\hline \multicolumn{7}{|l|}{ Age in years } \\
\hline $15-24$ & 1 & Reference & - & 1 & Reference & - \\
\hline $25-34$ & 2.33 & $1.91,2.85$ & $<0.001$ & 1.82 & $1.42,2.32$ & $<0.001$ \\
\hline $35-44$ & 1.55 & $1.22,1.97$ & $<0.001$ & 1.29 & $0.96,1.74$ & 0.092 \\
\hline $45-54$ & 1.34 & $1.03,1.75$ & 0.030 & 1.23 & $0.87,1.74$ & 0.233 \\
\hline 55 or more & 0.88 & $0.68,1.15$ & 0.345 & 0.89 & $0.65,1.22$ & 0.468 \\
\hline \multicolumn{7}{|l|}{ Education } \\
\hline Grade $0-7$ & 1 & Reference & - & 1 & Reference & - \\
\hline Grade 8-11 & 2.18 & $1.75,2.71$ & $<0.001$ & 1.52 & $1.18,1.97$ & $<0.001$ \\
\hline Grade 12 or more & 1.79 & $1.44,2.33$ & $<0.001$ & 1.40 & $1.05,1.87$ & 0.024 \\
\hline \multicolumn{7}{|l|}{ Population group } \\
\hline African black people & 1 & Reference & - & 1 & Reference & - \\
\hline mixed race & 1.04 & $0.83,1.30$ & 0.747 & 0.97 & $0.77,1.51$ & 0.823 \\
\hline Indian or Asian people & 0.50 & $0.37,0.69$ & $<0.000$ & 0.40 & $0.28,0.57$ & $<0.001$ \\
\hline \multicolumn{7}{|l|}{ Employment status } \\
\hline $\begin{array}{l}\text { Employed/self- } \\
\text { employed }\end{array}$ & 1 & Reference & - & 1 & Reference & - \\
\hline Unemployed & 1.00 & $0.83,1.19$ & 0.960 & 1.14 & $0.92,1.42$ & 0.230 \\
\hline Student/pupil/learner & 0.41 & $0.30,0.54$ & $<0.001$ & 1.93 & $0.82,4.53$ & 0.133 \\
\hline $\begin{array}{l}\text { Sick/disabled/unable to } \\
\text { work/others }\end{array}$ & 0.82 & $0.47,1.43$ & 0.476 & 1.24 & $0.63,2.42$ & 0.530 \\
\hline \multicolumn{7}{|l|}{ Residence } \\
\hline Rural informal & 1 & Reference & - & 1 & Reference & - \\
\hline Rural farms & 1.18 & $0.83,1.67$ & 0.360 & 1.03 & $0.70,1.51$ & 0.889 \\
\hline Urban & 1.84 & $1.44,2.34$ & $<0.001$ & 1.70 & $1.29,2.23$ & $<0.001$ \\
\hline \multicolumn{7}{|l|}{$\begin{array}{l}\text { Drug use (past } 3 \\
\text { months) }\end{array}$} \\
\hline No & 1 & Reference & - & 1 & Reference & - \\
\hline Yes & 3.11 & $2.54,3.80$ & $<0.001$ & 2.79 & $2.25,3.46$ & $<0.001$ \\
\hline Yes & 1.46 & $1.20,1.78$ & $<0.001$ & 1.42 & $1.16,1.75$ & $<0.001$ \\
\hline
\end{tabular}

$\mathrm{OR}$, odds ratio; $\mathrm{Cl}$, confidence interval. 


\section{Associations with hazardous, harmful or dependent alcohol}

In adjusted logistic regression analysis, amongst men who are middle age (25-34 year olds) with higher education, urban residence, drug use and psychological distress were positively associated, whereas Indian or Asian and white population groups were negatively associated with HHDA. Amongst women who are middle age (25-34 year olds), mixed race and residing on rural farms and urban areas with drug use and psychological distress were positively associated and older age (55 years and older) and Indians or Asians were negatively associated with HHDA (see Tables 3 and 4).

\section{Associations with drug use}

In adjusted logistic regression analysis, men having Grade 8-11 education, who are mixed race and unemployed and have HHDA use were positively and middle and older age (25 years and older) and a student or learner were negatively associated with past 3-month drug use. Women who are mixed race, Indians or Asians and have HHDA use were positively and older age (45 years and older) were negatively associated with past 3-month drug use (see Tables 5 and 6).

\section{Discussion}

Compared to previous national population-based surveys in $2008\left(9.0 \% \mathrm{HHDA}^{10}\right)$ and 2012 (4.4\% past 3-month drug use $\left.{ }^{14}\right)$ and a national survey in Kenya (6.7\% HHDA), ${ }^{9}$ this national survey in 2017 showed higher rates of HHDA (10.3\%) and any past 3-month drug use (8.6\%) (see Table 7). Similarly, Harker et al. $^{24}$ found an increase of opioid use disorder treatment admissions from $16.1 \%$ in 2012 to $20.0 \%$ in 2017 in South Africa. Reasons for the overall slight increase of HHDA and increase in any drug use in South Africa from 2008 or 2012 to 2017 need further research. ${ }^{25}$

In agreement with previous studies, ${ }^{6,7,8,14,26,27}$ this study found that male sex increased the odds and older age decreased the odds of HHDA and drug use. Sex-specific role expectations and norms, such as associating drinking alcohol and drug use with masculinity, may be related to the male preponderance of HHDA and drug use. ${ }^{7,28}$ In older age, in this study amongst women, a reduction of HHDA may be expected because the tolerance towards alcohol reduces with ageing. ${ }^{29}$

Amongst different population or ethnic groups in South Africa, mixed race women had significantly higher odds for HHDA and drug use. This result concurs with previous

TABLE 4: Associations with hazardous, harmful or dependent alcohol consumption amongst women.

\begin{tabular}{|c|c|c|c|c|c|c|}
\hline \multirow[t]{2}{*}{ Variable } & \multicolumn{3}{|c|}{ Simple logistic regression } & \multicolumn{3}{|c|}{ Multiple logistic regression } \\
\hline & Crude OR & $95 \% \mathrm{Cl}$ & $p$ & Adjusted OR & $95 \% \mathrm{Cl}$ & $p$ \\
\hline \multicolumn{7}{|l|}{ Age in years } \\
\hline $15-24$ & 1 & Reference & - & 1 & Reference & - \\
\hline $25-34$ & 1.72 & $1.24,2.36$ & $<0.001$ & 1.72 & $1.25,2.36$ & $<0.001$ \\
\hline $35-44$ & 1.00 & $0.69,1.47$ & 0.982 & 1.01 & $0.69,1.47$ & 0.962 \\
\hline $45-54$ & 0.93 & $0.64,1.34$ & 0.68 & 0.88 & $0.61,1.27$ & 0.502 \\
\hline 55 or more & 0.38 & $0.24,0.59$ & $<0.001$ & 0.4 & $0.25,0.63$ & $<0.001$ \\
\hline \multicolumn{7}{|l|}{ Education } \\
\hline Grade 0-7 & 1 & Reference & - & 1 & Reference & - \\
\hline Grade 8-11 & 1.54 & $1.17,2.02$ & 0.002 & 1.13 & $0.83,1.53$ & 0.455 \\
\hline Grade 12 or more & 1.15 & $0.89,1.48$ & 0.285 & 0.82 & $0.62,1.09$ & 0.174 \\
\hline \multicolumn{7}{|l|}{ Population group } \\
\hline African black people & 1 & Reference & - & 1 & Reference & - \\
\hline mixed race & 2.32 & $1.77,3.02$ & $<0.001$ & 1.98 & $1.49,2.63$ & $<0.001$ \\
\hline White people & 0.9 & $0.56,1.44$ & 0.668 & 0.95 & $0.58,1.56$ & 0.854 \\
\hline \multicolumn{7}{|l|}{ Employment status } \\
\hline Employed/self-employed & 1 & Reference & - & - & - & - \\
\hline Unemployed & 0.90 & $0.68,1.19$ & 0.460 & - & - & - \\
\hline Student/pupil/learner & 0.71 & $0.43,1.18$ & 0.189 & - & - & - \\
\hline Sick/disabled/unable to work/others & 0.54 & $0.18,1.65$ & 0.280 & - & - & - \\
\hline \multicolumn{7}{|l|}{ Residence } \\
\hline Rural informal & 1 & Reference & - & 1 & Reference & - \\
\hline Rural farms & 3.52 & $2.13,5.82$ & $<0.001$ & 2.57 & $1.51,4.38$ & $<0.001$ \\
\hline Urban & 3.28 & $2.35,4.57$ & $<0.001$ & 2.87 & $1.99,4.14$ & $<0.001$ \\
\hline \multicolumn{7}{|l|}{ Drug use (past 3 months) } \\
\hline No & 1 & Reference & - & 1 & Reference & - \\
\hline Yes & 3.18 & $2.15,4.69$ & $<0.001$ & 2.91 & $1.94,4.36$ & $<0.001$ \\
\hline \multicolumn{7}{|l|}{ Psychological distress } \\
\hline
\end{tabular}

$\mathrm{OR}$, odds ratio; $\mathrm{Cl}$, confidence interval. 
TABLE 5: Associations with drug use amongst men.

\begin{tabular}{|c|c|c|c|c|c|c|}
\hline \multirow[t]{2}{*}{ Variable } & \multicolumn{3}{|c|}{ Simple logistic regression } & \multicolumn{3}{|c|}{ Multiple logistic regression } \\
\hline & Crude OR & $95 \% \mathrm{Cl}$ & $p$ & Adjusted OR & $95 \% \mathrm{Cl}$ & $p$ \\
\hline \multicolumn{7}{|l|}{ Age in years } \\
\hline $15-24$ & 1 & Reference & - & 1 & Reference & - \\
\hline $25-34$ & 1.19 & $0.95,1.50$ & 0.126 & 0.81 & $0.62,1.04$ & 0.102 \\
\hline $35-44$ & 0.75 & $0.59,0.95$ & 0.019 & 0.53 & $0.41,0.70$ & $<0.001$ \\
\hline $45-54$ & 0.58 & $0.43,0.78$ & $<0.001$ & 0.4 & $0.29,0.56$ & $<0.001$ \\
\hline 55 or more & 0.36 & $0.27,0.48$ & $<0.001$ & 0.26 & $0.19,0.35$ & $<0.001$ \\
\hline \multicolumn{7}{|l|}{ Education } \\
\hline Grade 0-7 & 1 & Reference & - & 1 & Reference & - \\
\hline Grade 8-11 & 2.01 & $1.64,2.47$ & $<0.001$ & 1.52 & $1.20,1.92$ & $<0.001$ \\
\hline Grade 12 or more & 1.16 & $0.95,1.42$ & 0.141 & 0.93 & $0.74,1.19$ & 0.581 \\
\hline \multicolumn{7}{|l|}{ Population group } \\
\hline African black people & 1 & Reference & - & 1 & Reference & - \\
\hline mixed race & 1.31 & $1.03,1.67$ & 0.027 & 1.32 & $1.03,1.69$ & 0.029 \\
\hline White people & 0.59 & $0.41,0.85$ & 0.005 & 0.83 & $0.56,1.24$ & 0.362 \\
\hline \multicolumn{7}{|l|}{ Employement status } \\
\hline Employed/self-employed & 1 & Reference & - & 1 & Reference & - \\
\hline Unemployed & 1.34 & $1.11,1.62$ & 0.002 & 1.27 & $1.02,1.58$ & 0.034 \\
\hline Student/pupil/learner & 0.7 & $0.52,0.93$ & 0.015 & 0.52 & $0.35,0.76$ & $<0.001$ \\
\hline Sick/disabled/unable to work/others & 0.77 & $0.43,1.36$ & 0.363 & 0.99 & $0.51,1.90$ & 0.965 \\
\hline \multicolumn{7}{|l|}{ Residence } \\
\hline Rural informal & 1 & Reference & - & - & - & - \\
\hline Rural farms & 1.05 & $0.75,1.46$ & 0.778 & - & - & - \\
\hline Urban & 1.24 & $0.98,1.55$ & 0.072 & - & - & - \\
\hline \multicolumn{7}{|c|}{ Hazardous/harmful/dependent alcohol use } \\
\hline No & 1 & Reference & - & 1 & Reference & - \\
\hline Yes & 3.12 & $2.57,3.78$ & $<0.001$ & 2.81 & $2.29,3.46$ & $<0.001$ \\
\hline \multicolumn{7}{|l|}{ Psychological distress } \\
\hline
\end{tabular}

$\mathrm{OR}$, odds ratio; $\mathrm{Cl}$, confidence interval.

studies in South Africa for both mixed race women and men. ${ }^{10,14}$ It is possible that people of mixed race (coloured) are exposed to more stressors than other population groups contributing to higher rates of substance use. Whilst previous research showed an association between lower education and lower socioeconomic status, ${ }^{10,30,31}$ this study did not find that educational level was associated with HHDA and drug use amongst women, whilst drug use amongst men with higher education was positively associated with HHDA and drug use. The findings amongst women are interesting and warrant further investigation to fully understand the change. Amongst men with higher education, the positive association could be explained because of rapid modernisation, which strongly correlates with drug use. ${ }^{32}$ As South Africa progresses from apartheid, there are an increasing number of people entering the higher education and middle-upper income bracket.

On the other hand, amongst men, unemployment increased the odds of drug use in this study, which is in line with a previous study in South Africa. ${ }^{26}$ As stated by Peltzer et al: ${ }^{32}$

$[U]$ se of drugs may be functional as it provides a form of release or escape not only for large numbers of unemployed (especially young men) who may also feel they are unemployable. (p. 2228)
Consistent with previous research findings, ${ }^{16,17,33}$ this study found strong associations between drug use, psychological distress and HHDA and drug use. This confirms the comorbity between HHDA and drug use and psychological distress, but comorbidity between drug use and HHDA but not psychological distress. Reasons for the comorbidity between HHDA and drug use may lie in the codependence risk of the substances used. Public health interventions should be directed at integrating drug use and psychological distress prevention in persons with HHDA

\section{Study limitations}

This study was limited by its cross-sectional design and self-report of data, including substance use. A further limitation was that in this household survey, populations using heavy substance, such as military personnel, homeless or institutionalised persons, were not included. ${ }^{34}$

\section{Conclusion}

In this large national population-based survey amongst persons 15 and older in 2017 in South Africa, about one in 10 participants engaged in HHDA and drug use, with several sociodemographic (male sex, middle age, higher education, being unemployed, mixed race, urban 
TABLE 6: Associations with drug use amongst women.

\begin{tabular}{|c|c|c|c|c|c|c|}
\hline \multirow[t]{2}{*}{ Variable } & \multicolumn{3}{|c|}{ Simple logistic regression } & \multicolumn{3}{|c|}{ Multiple logistic regression } \\
\hline & Crude OR & $95 \% \mathrm{Cl}$ & $p$ & Adjusted OR & $95 \% \mathrm{Cl}$ & $p$ \\
\hline \multicolumn{7}{|l|}{ Age in years } \\
\hline $15-24$ & 1 & Reference & - & 1 & Reference & - \\
\hline $25-34$ & 0.87 & $0.64,1.18$ & 0.367 & 0.85 & $0.63,1.16$ & 0.308 \\
\hline $35-44$ & 0.72 & $0.50,1.03$ & 0.069 & 0.71 & $0.50,1.01$ & 0.054 \\
\hline $45-54$ & 0.68 & $0.45,1.02$ & 0.061 & 0.64 & $0.43,0.96$ & 0.032 \\
\hline 55 or more & 0.6 & $0.43,0.84$ & 0.003 & 0.57 & $0.40,0.80$ & $<0.001$ \\
\hline \multicolumn{7}{|l|}{ Education } \\
\hline Grade $0-7$ & 1 & Reference & - & - & - & - \\
\hline Grade 8-11 & 0.94 & $0.68,1.26$ & 0.624 & - & - & - \\
\hline Grade 12 or more & 1.09 & $0.83,1.44$ & 0.523 & - & - & - \\
\hline \multicolumn{7}{|l|}{ Population group } \\
\hline African black people & 1 & Reference & - & 1 & Reference & - \\
\hline mixed race & 1.84 & $1.36,2.62$ & $<0.001$ & 1.70 & $1.25,2.30$ & $<0.001$ \\
\hline White people & 1.68 & $1.08,1.62$ & 0.022 & 1.94 & $1.22,3.07$ & 0.005 \\
\hline \multicolumn{7}{|l|}{ Employment status } \\
\hline Employed/self-employed & 1 & Reference & - & - & - & - \\
\hline Unemployed & 0.99 & $0.74,1.31$ & 0.922 & - & - & - \\
\hline Student/pupil/learner & 1.14 & $0.79,1.63$ & 0.482 & - & - & - \\
\hline Sick/disabled/unable to work/others & 0.89 & $0.41,1.95$ & 0.775 & - & - & - \\
\hline \multicolumn{7}{|l|}{ Residence } \\
\hline Rural informal & 1 & Reference & - & - & - & - \\
\hline Rural farms & 1.17 & $0.63,2.19$ & 0.615 & - & - & - \\
\hline Urban & 1.2 & $0.85,1.71$ & 0.301 & - & - & - \\
\hline \multicolumn{7}{|c|}{ Hazardous/harmful/dependent alcohol use } \\
\hline No & 1 & Reference & - & 1 & Reference & - \\
\hline Yes & 3.43 & $2.37,4.95$ & $<0.001$ & 3.08 & $2.11,4.49$ & $<0.001$ \\
\hline \multicolumn{7}{|l|}{ Psychological distress } \\
\hline No & 1 & Reference & - & - & - & - \\
\hline
\end{tabular}

$\mathrm{OR}$, odds ratio; $\mathrm{Cl}$, confidence interval.

TABLE 7A: Prevalence of hazardous, harmful or dependent alcohol consumption and drug use across national surveys in South Africa.

\begin{tabular}{|c|c|c|c|c|c|c|}
\hline \multirow[t]{3}{*}{ Study year } & \multicolumn{3}{|c|}{ Hazardous, harmful or dependent alcohol use } & \multicolumn{3}{|c|}{ Any drug use } \\
\hline & Total & Male & Female & Total & Male & Female \\
\hline & $\%$ & $\%$ & $\%$ & $\%$ & $\%$ & $\%$ \\
\hline $2008^{15}$ & 9.0 & 17.0 & 2.9 & $3.3^{26}$ & - & - \\
\hline $2012^{14}$ & - & - & - & 4.4 & 7.9 & 1.3 \\
\hline 2017 & 10.3 & 16.5 & 4.6 & 8.6 & 13.3 & 4.1 \\
\hline
\end{tabular}

TABLE 7B: Prevalence of hazardous, harmful or dependent alcohol consumption and drug use across national surveys in South Africa.

\begin{tabular}{|c|c|c|c|c|c|c|c|}
\hline \multirow[t]{4}{*}{ Study year } & \multicolumn{7}{|c|}{ Drug use } \\
\hline & Cannabis & Cocaine & Amphetamine & Inhalants & Sedatives & Hallucinogens & Opiates \\
\hline & Total & Total & Total & Total & Total & Total & Total \\
\hline & $\%$ & $\%$ & $\%$ & $\%$ & $\%$ & $\%$ & $\%$ \\
\hline $2008^{26}$ & 3.2 & 0.7 & 0.8 & 0.8 & 0.7 & 0.7 & 0.7 \\
\hline $2012^{14}$ & 4.0 & 0.3 & 0.3 & 0.2 & 0.4 & 0.1 & 0.1 \\
\hline 2017 & 7.8 & 1.8 & 1.5 & 1.3 & 1.7 & 1.2 & 1.2 \\
\hline
\end{tabular}

residence) and health indicators (substance use and psychological distress), was identified to be associated with HHDA and/or any drug use.

\section{Acknowledgements}

We acknowledge Human Sciences Research Council; South African National HIV Prevalence, HIV Incidence, Behaviour and Communication Survey (SABSSM) 2017: Combined - All provinces. (Data set). SABSSM 2017
Combined. Version 1.0; Pretoria South Africa: Human Sciences Research Council (producer) 2017; and Human Sciences Research Council (distributor) 2020. https:/ / doi. org/doi:10.14749/1585345902.

\section{Competing interests}

The authors declare that they have no financial or personal relationships, which may have inappropriately influenced them in writing this article. 


\section{Authors' contributions}

All authors fulfil the criteria for authorship. S.P., S.R. and K.P. conceived and designed this research, performed the statistical analysis, drafted this manuscript and made critical revision of this manuscript for key intellectual content. All authors have read and agreed to the published version of this manuscript.

\section{Funding information}

Bill and Melinda Gates Foundation, Centers for Disease Control and Prevention Human Sciences Research Council, President's Emergency Plan for AIDS Relief (Emergency Plan), South African National AIDS Council and United Nations Children's Fund funded this work.

\section{Data availability}

The data are available at Human Sciences Research Council (distributor) 2020. http:/ /dx.doi.org/doi:10.14749/1585345902.

\section{Disclaimer}

The views and opinions expressed in this article are those of the authors and do not necessarily reflect the official policy or position of any affiliated agency of the authors.

\section{References}

1. Shield K, Manthey J, Rylett M, et al. National, regional, and global burdens of disease from 2000 to 2016 attributable to alcohol use: A comparative risk assessment study. Lancet Public Health. 2020;5(1):e51-e61. https://doi.org/ 10.1016/S2468-2667(19)30231-2

2. United Nations Office on Drugs and Crime. World drug report 2016. New York, NY: United Nations Publication, Sales No. E.16.XI.7; 2016

3. Degenhardt L, Whiteford HA, Ferrari AJ, et al. Global burden of disease attributable to illicit drug use and dependence: Findings from the global burden of disease study 2010. Lancet. 2013;382(9904):1564-1574. https://doi.org/10.1016/S01406736(13)61530-5

4. Schneider M, Norman R, Parry C, Bradshaw D, Plüddemann A, South African Comparative Risk Assessment Collaborating Group. Estimating the burden of disease attributable to alcohol use in South Africa in 2000. S Afr Med J. 2007;97 (8 Pt 2):664-672.

5. Clausen T, Rossow I, Naidoo N, Kowal P. Diverse alcohol drinking patterns in 20 African countries. Addiction. 2009;104(7):1147-1154. https://doi.org/10.1111/ j.1360-0443.2009.02559.x

6. Agoudavi K, Dalmay F, Legleyle $S$, et al. Epidemiology of alcohol use in the general population of Togo. Addict Behav Rep. 2015;2:1-5. https://doi.org/10.1016/j. abrep.2015.03.004

7. Kabwama SN, Ndyanabangi S, Mutungi G, Wesonga R, Bahendeka SK, Guwatudde D. Alcohol use among adults in Uganda: Findings from the countrywide noncommunicable diseases risk factor cross-sectional survey. Glob Health Action. 2016;9:31302. https://doi.org/10.3402/gha.v9.31302

8. Pires J, Padrão P, Damasceno A, Silva-Matos C, Lunet N. Impact of different reference period definitions in the quantification of alcohol consumption: Results from a nationwide STEPS survey in Mozambique. Alcohol Alcohol. 2012;47(3): 328-333. https://doi.org/10.1093/alcalc/ags003

9. Pengpid S, Peltzer K. Alcohol use among adults in Kenya: Results from the national non-communicable diseases risk factor survey, 2015. J Psychol Afr. 2019;29(1): 49-53. https://doi.org/10.1080/14330237.2019.1568728

10. Peltzer K, Davids A, Njuho P. Alcohol use and problem drinking in South Africa: Findings from a national population-based survey. Afr J Psychiatry. 2011;14(1): 30-37. https://doi.org/10.4314/ajpsy.v14i1.65466
11. Peacock A, Leung J, Larney S, et al. Global statistics on alcohol, tobacco and illicit drug use: 2017 status report. Addiction. 2018;113(10):1905-1926. https://doi. org/10.1111/add.14234

12. Degenhardt L, Bharat C, Glantz MD, et al. The epidemiology of drug use disorders cross-nationally: Findings from the WHO's world mental health surveys. Int J Drug Policy. 2019;71:103-112. https://doi.org/10.1016/j.drugpo.2019.03.002

13. Obot IS. Drugs in the Nigerian population: Availability, use, consequences and policy implications. Bull Narc [serial online]. 2019 [cited 2020 Jan 5]; LXII:1-9. Available from: https://www.crisaafrica.org/wp-content/uploads/2020/08/Bulletin-19-11671_ ebook.pdf\#page=13. https://doi.org/10.18356/4a466a75-en

14. Peltzer K, Phaswana-Mafuya N. Drug use among youth and adults in a populationbased survey in South Africa. S Afr J Psychiatr. 2018;24:1139. https://doi.org/ 10.4102/sajpsychiatry.v24i0.1139

15. Peltzer K, Pengpid, S. Alcohol use and problem drinking in South Africa: Results from a national-population-based survey 2014-2015. J Psychol Afr. 2018;28(2): 147-151. https://doi.org/10.1080/14330237.2017.1375230

16. Lai HM, Cleary M, Sitharthan T, Hunt GE. Prevalence of comorbid substance use, anxiety and mood disorders in epidemiological surveys, 1990-2014: A systematic review and meta-analysis. Drug Alcohol Depend. 2015;154:1-13. https://doi. org/10.1016/j.drugalcdep.2015.05.031

17. Jané-Llopis E, Matytsina I. Mental health and alcohol, drugs and tobacco: A review of the comorbidity between mental disorders and the use of alcohol, tobacco and illicit drugs. Drug Alcohol Rev. 2006;25(6):515-536. https://doi.org/10.1080/ 09595230600944461

18. Simbayi LC, Zuma K, Zungu N, et al. South African national HIV prevalence, incidence, behaviour and communication survey, 2017. Cape Town: HSRC Press; 2019.

19. Statistics South Africa. Mid-year population estimates 2017. Pretoria: Stats SA; 2017.

20. Babor TF, Higgens-Biddle JC, Saunders JB, Monteiro MG. AUDIT: The alcohol use disorders identification test. Guidelines for use in primary care. Geneva: World Health Organization, Department of Mental Health and Substance Dependence; 2001.

21. Liskola J, Haravuori $\mathrm{H}$, Lindberg $\mathrm{N}$, et al. AUDIT and AUDIT-C as screening instruments for alcohol problem use in adolescents. Drug Alcohol Depend. 2018;188:266-273. https://doi.org/10.1016/j.drugalcdep.2018.04.015

22. Humeniuk RE, Henry-Edwards S, Ali RL, Poznyak V, Monteiro M. The alcohol, smoking and substance involvement screening test (ASSIST): Manual for use in primary care. Geneva: World Health Organization; 2010.

23. Kessler RC, Andrews G, Colpe LJ, et al. Short screening scales to monitor population prevalences and trends in non-specific psychological distress. Psychol Med. 2002;32(6):959-976. https://doi.org/10.1017/\$0033291702006074

24. Harker N, Lucas WC, Laubscher R, Dada S, Myers B, Parry CD. Is South Africa being spared the global opioid crisis? A review of trends in drug treatment demand for heroin, nyaope and codeine-related medicines in South Africa (2012-2017). Int Drug Policy. 2020;83:102839. https://doi.org/10.1016/j.drugpo.2020.102839

25. Ramlagan S, Peltzer K, Pengpid S. Prevalence and correlates of non-daily and daily cannabis use among persons 15 years and older in South Africa: Results of a national survey in 2017. Preprint from Research Square, 2020 Dec 3. https://doi. org/10.21203/rs.3.rs-116225/v1

26. Peltzer K, Ramlagan S. Illicit drug use in South Africa: Findings from a 2008 national population-based survey. S Afr J Psychiatr. 2010;16(1):8-15. https://doi. org/10.4102/sajpsychiatry.v16i1.230

27. Phillips MR, Cheng HG, Li X, et al. Prevalence, correlates, comorbidity, and age of onset of alcohol use disorders in adult males from five provinces in China. Drug Alcohol Depend. 2017;173:170-177. https://doi.org/10.1016/j.drugalcdep.2016. 12.026. https://www.niaaa.nih.gov/alcohols-effects-health/special-populationsco-occurring-disorders/older-adults

28. Kassa A, Taddesse F, Yilma A. Prevalence and factors determining psychoactive substance (PAS) use among Hawassa University (HU) undergraduate students, Hawassa Ethiopia. BMC Public Health. 2014;14:1044. https://doi.org/10.1186/ 1471-2458-14-1044

29. Institute of Alcohol Studies. Older people's drinking habits, 2017 [homepage on the Internet]. [cited 2020 Aug 30]. Available from: https://www.niaaa.nih.gov/ alcohols-effects-health/special-populations-co-occurring-disorders/older-adults

30. Allen L, Williams J, Townsend $\mathrm{N}$, et al. Socioeconomic status and noncommunicable disease behavioural risk factors in low-income and lower-
middle-income countries: A systematic review. Lancet Global Health. 2017;5(3): e277-e289. https://doi.org/10.1016/S2214-109X(17)30058-X 31. Assari S, Farokhnia M, Mistry R. Education attainment and alcohol binge drinking:
Diminished returns of Hispanics in Los Angeles. Behav Sci. 2019;9(1):9. https:// doi.org $/ 10.3390 /$ bs9010009

32. Peltzer K, Ramlagan S, Johnson BD, Phaswana-Mafuya N. Illicit drug use and treatment in South Africa: A review. Subst Use Misuse. 2010;45(13):2221-2243. https://doi.org/10.3109/10826084.2010.481594

33. Peltzer K, Chao LW, Ramlagan S, Szrek H. Daily tobacco use and problem drinking among urban adults in South Africa: A longitudinal study. Pan Afr Med J. 2019;32:51. https://doi.org/10.11604/pamj.2019.32.51.17256

34. Rehm J, Crépault JF, Wettlaufer A, Manthey J, Shield K. What is the best indicator of the harmful use of alcohol? A narrative review. Drug Alcohol Rev. 2020;39(6): 624-631. https://doi.org/10.1111/dar.13053 